УДК 23/28

\title{
ПРОРОЧЕСКОЕ СЛУЖЕНИЕ СВЯТОГО ДАНИИЛА КАК ПРИМЕР ОСОБОЙ МИССИИ ПРЕД БОГОМ И ЛЮДЬМИ
}

\author{
Плохий Евгений Викторович \\ слушатель \\ Религиозная организация - духовная образовательная \\ организация высшего образования \\ Белгородская Православная Духовная \\ семинария (с миссионерской направленностью) \\ Православной религиозной организации \\ Белгородской и Старооскольской епархии \\ Русской Православной Церкви Московского Патриархата \\ город Белгород, Российская Федерация
}

\begin{abstract}
Аннотация. Автором данной научно - исследовательской работы рассмотрен и проанализирован важный аспект пророческого служения святого пророка Даниила - служение Богу и людям как миссия и проповедь. Также автором научно - исследовательской работы обоснованы и показаны актуальность и значение миссионерского подвига святого пророка Даниила как особого вида пророческой проповеди и служения Богу для православного богословия и каждого современного человека.
\end{abstract}

Ключевые слова: философия, православное богословие, библеистика, Ветхий Завет, Книга пророка Даниила, личность, пророчество.

\section{THE PROPHETIC MINISTRY OF ST. DANIEL AS AN EXAMPLE OF A SPECIAL MISSION BEFORE GOD AND PEOPLE}

\section{Plokhii Yevgenii Viktorovich}

\begin{abstract}
The author of this research work considers and analyzes an important aspect of the prophetic ministry of the holy Prophet Daniel - serving God and people as a mission and preaching. Also, the author of the research work substantiates and shows the relevance and significance of the missionary feat of the
\end{abstract}


holy Prophet Daniel as a special type of prophetic preaching and service to God for Orthodox theology and every modern person.

Key words: philosophy, Orthodox theology, Biblical studies, the Old Testament, the Book of the Prophet Daniel, personality, prophecy.

Священное Писание Ветхого и Нового Завета [1] многократно утверждает факт исключительности пророческого служения и характеризует его не только как дар от Бога, но и как подвиг человека. Пророческое служение святого пророка Даниила - это особая миссия, которую он выполнял перед Богом, своим народом и всем человечеством: «Пророчество как особенный дар от Бога, было дано святому пророку Даниилу для того, чтобы возвещать будущее, и являться видимым доказательством его истинной связи с Богом»[2, с. 243].

Начало пророческого служения святого Даниила связано с его пленением в юном возрасте царём Навуходоносором и переселением в Вавилон. Пребывание в плену было сопряжено со многими трудностями, скорбями и испытаниями. В частности, можно упомянуть очень важное событие в жизни юных пленников - смену имён. Пленённым отрокам в Вавилоне нарекли новые имена: «И переименовал их начальник евнухов - Даниила Валтасаром, Ананию Седрахом, Мисаила Мисахом и Азарию Авденаго» (Дан. 1, 7). Эти новые имена отрокам были даны в честь языческих богов: Валтасар - означает охраняемый Ваалом, имена Седрах, Мисах и Авденаго также прославляли шумероаккадских богов. Так Царь желает показать свою власть в том, что он силён изменить даже то, что дано было родителями при рождении и обрезании. Наречение имени было связано с религиозным обрядом иудеев. Таким образом, наречение нового халдейского имени было знаком того, что отроки стали новыми людьми, принадлежащими уже культурной традиции Вавилона.

В православной Церкви при крещении человеку часто меняют имя. И если имя не христианское, то оно меняется обязательно. И это происходит как знак перемены жизни, начало новой жизни. Также, новое имя даётся человеку при монашеском постриге как знак новой жизни.

Также и в иудейской традиции: наречение имени - это знак новых отношений с Богом, новой жизни. Например, имя Даниил означает - «Бог мне судья»; имя Анания - «Яхве возвысил меня»; имя Мисаил - «испрошенный у Бога»; имя Азария - «Яхве помог». Имена пророка Даниила и его друзей являются теофорными, то есть содержащими в себе имя Бога. Поэтому новые 
имена, данные отрокам в Вавилоне, теперь уже соотносились с новыми божествами и тоже были теофорными, только в честь языческих богов.

Исходя из всего этого, становится понятной важность имени в жизни человека. Сегодня мы можем наблюдать развитие молодёжной культуры. Мир хочет поменять наших детей. Например, кроме имени, практически каждому ребёнку его сверстники дают какую - то кличку, прозвище. Здесь мы можем провести параллель с наречением нового имени. Мир субкультурных сообществ навязывает молодым людям свои ценности. По сути, этого же желал Вавилонский царь Навуходоносор в отношении Даниила и пленённых отроков.

В связи с вышеизложенным, важно ещё раз отметить, что каждого ребёнка уже с детства необходимо называть полным именем. Именно это будет способствовать формированию его культурной идентичности. Например, упомянутые выше, еврейские юноши, невзирая на то, что получили другие имена, с благоговением относились к своим первоначальным именам, показывая преданность своему народу, Родине и верность иудейским традициям.

Тем не менее, всё же может возникнуть вопрос, какую основную цель преследовал царь Навуходоносор, приобщая иудейских юношей к культуре Вавилонского царства. В первую очередь, это нужно было для того, чтобы они отреклись от своей веры, а для этого они должны были поклоняться языческим богам как все остальные жители Халдейского царства. Примером яркой иллюстрации такого приобщения к своим традициям является приказ Навуходоносора принимать еврейским отрокам пищу с царского стола: «И назначил им иарь ежедневную пищу с иарского стола и вино, которое сам пил, и велел воспитывать их три года, по истечении которых они должны были предстать пред царя» (Дан. 1, 5). Учитывая то, что на этом столе вполне могла быть идоложертвенная еда, вкушение которой запрещено ветхозаветным Законом Моисея, такого рода внешней привилегией царь Навуходоносор хотел сломить волю юношей, и заставить забыть Закон своих предков, связав их обязательствами, чтобы они в дальнейшем не могли восстать против Халдейского царства и против него самого.

В таких обстоятельствах святые отроки решают остаться верными Богу и Его Закону. Свою жизнь юноши мыслили, как постоянное предстояние перед Богом. Примером в этом служении для них были все ветхозаветные праведники: «Перед Богом ходили практически все патриархи, и поэтому 
«хождение перед Богом» можно назвать как служением патриархов, так и выражением их веры» [3, с. 21].

В Книге пророка Даниила также сказано, что пророк Даниил положил в сердце своём не оскверняться пищей с царского стола: "Даниил положил в сердие своём не оскверняться яствами со стола царского и вином, какое пьёт иарь, и потому просил начальника евнухов о том, чтобы не оскверняться ему» (Дан. 1,8$)$. Он попросил распорядителя давать ему и другим трём юношам воду и овощи. Помощник царского евнуха согласился, убедившись, что никакого вреда от такой пищи отроки не получают, но наоборот, увидел лица юношей красивее, чем у остальных, а тела полнее. Иными словами, пророк Даниил со своими друзьями Ананием, Мисаилом и Азарией оградили себя от участия в чуждой им религиозной жизни, то есть наложили на себя пост, чтобы воздерживаться от всего, что могло быть осквернённым.

В связи с этим, уместно вспомнить слова преподобного Ефрема Сирина, который пишет, что пророк Даниил воздерживался не потому, что не чиста была пища и питие, так как мог бы и мясо заменять одно другим, и вино также, и не оскверняться, но потому, что он и товарищи его посвятили себя посту. И вот мы видим, как Господь показал, что пост не является вредным для здоровья, когда он совершается ради Бога, а напротив, является полезным для человека [4].

По утверждению святителя Василия Великого, душевные способности молодого поколения необходимо не только воспитывать, но и направлять на достижение высшей цели. В традициях семьи закладываются не только основы личности, но также и будущих свершений и подвигов человека, о чём свидетельствует и жизнь самого святителя Василия Великого: «Личность святителя Василия как великого защитника христианства начала формироваться в раннем возрасте. С самого начала своей жизни он был воспитан как христианин - в любви к Богу и ближним. Впоследствии «многие члены семьи святителя Василия Великого были причислены к лику святых» христианской церковью: прежде всего, сам Василий Великий, его отец - святой Василий Старший, пресвитер, его мама - преподобная Емилия Кесарийская; его братья - святитель Григорий Нисский, святитель Пётр Севастийский и праведный Навкратий Кесарийский, его сёстры - блаженная Феосевия (Феозва) диаконисса, преподобная Макрина Каппадокийская и его бабушка исповедница Макрина Старшая» [5, с. 130]. Таким образом, мы видим, что для человека 
именно семья является самым главным училищем благочестия и стяжания добродетелей.

На примере пророка Даниила и его друзей мы видим, что нелицемерный пост, мужественная преданность Богу, горячая молитва, скромность, смирение и многие другие добродетели предшествовали их успехам в получении знаний. Такое поведение юношей являлось их осознанным выбором и, по сути, их миссионерским подвигом и исповеданием веры (Дан. 3, 1 - 97), поскольку «выбор добродетельных и порочных действий - во власти человека» [6, с. 162]. По великому дару от Бога юноши были наделены многими талантами, в том числе, отличались успехами в постижении наук и пониманием духовного смысла заповедей Божиих. О причинах таких дарований рассуждает святитель Василий Великий: «без духовно-нравственного преображения, совершенствования и бытия человека невозможно правильное понимание и толкование Священного Писания, поскольку основное видение очами духовными доступно только христианам» [7, с. 145]. Именно поэтому в обучении пророк Даниил достиг необычайных результатов: «B десять раз стал выне всех тайноведиев и волхвов» (Дан. 1, 20), во всём Вавилонском царстве.

Вся жизнь пророка Даниила стала подвигом пророческого исповедания истинной веры - мессионерством, а также пророческой проповедью веры в Единого Истинного Бога среди язычников - миссионерством. Пророческое служение святого Даниила важно не только в историческом контексте, но актуально и значимо для современного человека, поскольку «всякий истинно благочестивый человек и разумно исповедующий свою религию должен добросовестно исследовать те основания и догматы, на которых держится и из которых слагается его религия» [8].

Пророк Даниил прожил долгую жизнь и умер, предположительно, в 90летнем возрасте в Сузах. Он вместе с тремя отроками иудейскими также и многими другими усопшими святыми согласно Церковному Писанию и Преданию воскресли и вышли из гробов после крестной смерти Спасителя (Мф. 27, 52 - 53). Пророк Даниил почитается Православной Церковью особо за предсказание прихода в мир Мессии. Память пророка Даниила и трёх отроков: Ана́нии, Аза́рии и Мисаи́ла совершается 17/30 декабря.

Таким образом, основной смысл пророческого служения святого пророка Даниила - это миссионерство, поскольку вся его жизнь, которая является высшим проявлением исповедания веры, служения Богу и людям представляет собой пророческую проповедь как миссию. 


\section{Список литературы}

1. Библия. - Москва: Российское Библейское Общество, 2020. - 1337 с.

2. Плохий Е. В. Личность пророка Даниила в контексте библейской истории. // Научный потенциал молодёжных исследований: сборник статей III Международной научно-практической конференции (3 мая 2021 года). Петрозаводск: МЦНП «Новая наука», 2021. - С. 242 - 248.

3. Гоголюк Юлиан, прот. Экзегетический анализ концепта «вера»в ранний период ветхозаветной истории. // Евангелие в контексте современной культуры: духовно - нравственные ценности и будущее человечества: сборник материалов VI Международной научно - практической конференции, 26 апреля 2018 г. / Под редакцией Т. И. Липич, С. М. Дергалева. - Белгород: ИД «Белгород» НИУ «БелГУ», 2018. - С. 20 - 22.

4. Ефрем Сирин, прп. Толкования на священное Писание. Книга пророка Даниила. [Электронный ресурс] - URL: https://azbyka.ru/otechnik/Efrem_Sirin/ tolkovanie-na-knigu-proroka-daniila/ (дата обращения: 18. 04. 2021).

5. Неганов В. В. Исходные положения и характеристики экзегетики каппадокийских Отцов Церкви (святитель Василий Великий). // Вестник Московского государственного областного университета. Серия: Философские науки. - Москва: Изд - во МГОУ, 2018. - № 3. - С. 129 - 138.

6. Байдакова М. Ю. Проблема воли в философии и христианской антропологии : Диссертация ... кандидата философских наук: 09.00.01. Москва, 2008. - 233 с.

7. Неганов В. В. Основные тенденции развития философских и богословских взглядов на допустимые методы толкования Священного Писания в экзегетике каппадокийских Отцов Церкви (святитель Василий Великий). // Вестник Московского государственного областного университета. Серия: Философские науки. - Москва: Изд - во МГОУ, 2018. - № 3. - С. 139 149.

8. Херасков Михаил, прот. Речь обратившемуся в православие из католицизма. [Электронный ресурс] - URL: https://azbyka.ru/otechnik/Mihail_ Heraskov/slova-pouchenija-i-rechi-s-tremja-opytami-vnetserkovnyh-sobesedovanij /51\#sel=8:312,8:363;8:278,8:302 (дата обращения: 18. 04. 2021).

(C) Е. В. Плохий, 2021 